\section{The Use of Regional Marketing in the Conduct of Regional Policy}

\section{Denisa Jánošová}

University of Ss. Cyril and Methodius in Trnava, Slovakia

https://orcid.org/0000-0003-2826-7463

\section{Tomasz Jobczyk} \\ University of Ss. Cyril and Methodius in Trnava, Slovakia \\ https://orcid.org/0000-0003-3694-8883
}

Political Preferences

2019, vol. 25: 53-62

journals.us.edu.pl/index.php/PP

Submitted: 30/11/2019

Accepted: 30/12/2019

\begin{abstract}
:
The purpose of the article is to demonstrate the close relationship between regional development and territorial marketing, which based on the implementation of the marketing concept focuses on creating regional and local products and their effective positioning towards potential buyers. The presented thesis is a result of reflection on using regional marketing in creating regional policy, based on consideration of the specific features of the region which marketing specialists are supposed to know in order to create a marketing plan for the respective region. Further, the marketing plan may be used in the political strategy of regional development based on the satisfaction of the residents' needs and their individual development. The care of politicians, who fulfil their functions following the election by the citizens, and the development of residents would coexist with the creation of regional development. The phenomena should be closely interrelated. When describing the interrelation from a scientific perspective, it must be said that synergy of the indicated types of activity depends on a series of facts and correlations which fall within various scientific domains. Therefore, there is a need for multidisciplinary approach. The authors of the article hypothesize that management of regional development should be supported by the professional use of regional marketing, taking into account the assumption that each organization should shape its impact system by analysing its needs, already used solutions and the needs of its stakeholders. The views expressed are based on the analysis of selected literature.
\end{abstract}

Keywords: regional policy, regional marketing, residents' needs, regional development 


\section{Introduction}

The issue of regional development on the country level within the globalisation process is extremely important. This refers not only to economic factors. First of all, it is related to the political, and further social, sociological and psychological influence of regionalisation on the residents of the region. If residents are not convinced about the development of the place they live in, and regions are not economically stable, it is difficult to talk about social and economic stability of the state. An effective regional policy requires stirring in the residents of the feeling that being properly managed they participate in a phenomenon of favourable economic trends. Growth of the importance of regions contributed to the development of a new scientific discipline which is commonly known under the term of regional science.

The interest in the development of a region is not completely new. It may not be perceived solely as a reply to the current globalisation trends. Formulation of spatial relationships by way of economic instruments appeared in the theory of economy already at the end of the 18th century. Initially, it referred to agricultural production, but at the beginning of industrial revolution it gradually started to appear in the economic theories of all sectors. At the same time, that resulted in a growing number of aspects with which we may differentiate and define a region. The specifics of the respective regions may be considered from various perspectives: economic, geographic, social, residential, cultural, etc. We refer to a multidisciplinary approach which enables a region determination by way of a broad range of aspects. On the other hand, that leads to a problem of finding a general definition of the term 'region'. Therefore, nearly all of the theoretical literary works begin with a statement that a universal definition of a region is highly problematic, because the limits of a certain space are always set out based on a previously defined objective.

Particularly important in the effective regional policy is the social and political communication of the public administration institutions and the residents of the region, because the type of communication is more anonymous than such communication in cities. Political communication may reach to methods of marketing communication strategy and avail of the same tools. Although the respective regions strive for the same objectives, both political communication and marketing communication in each of them will have their own characteristic features. The issue refers equally to internal and external communication. They may be created and organised differently in the different regions. There are, however, common features that may 
be described in a scientific manner. When we start to develop a marketing mix, within the selected method, we ask ourselves two fundamental questions - what is the goal and who do we want to address (Kita 2001). De Vito, who in the connection with the intercultural differences, points out to the fact (which should be noted and accepted also in the marketing), that within the cultural dimension we have to distinguish not only the cross-cultural specifics, but also the differences within individual cultures. In other words - every major culture is composed of subcultures of various ethnic groups that are represented in the society. According to De Vito, these cultures live next to each other in relative isolation, with no tendency to interact. Some theorists call these subcultures "co-culture" (DeVito 2001). An important role for the formation of natural regions, which are developed on the natural, socio-economic, cultural and historical base, is the so-called regional identity (Strussová 2007).

Regional development is not only a political problem but also a marketing one when viewed from another research and practical perspective. The issues overlap. Important is the awareness among the researchers that beside the social and economic differences a growing role is played by the regional differences of the researched regions. The more so because regions evolve along with the inflow of immigrants whose culture and professional characteristics may be significantly different to those of the local people. What is more, when analysing demographic phenomena as well as the social and political situation of the western European countries, the effect will intensify. Europe has been changing its face, which forces a new approach in regional policy that, when well created and managed, should use the experiences of regional marketing. The marketing focuses on regional and local products and is to promote them to find buyers, tourists, investors and new residents.

In the literature available, only general categories of the issue may be found. In practice, every region following the formal grounds of local-government activities develops its own strategy of operation, a part of which refers to relations with the environment. An analysis of the strategies of provincial governments indicates that they focus mainly on political indications. The accompanying document, in which development is determined with the use of marketing, comes down to the strategy of promotion. Marketing strategy is a rare document in the Polish local government units and, if any, its contents describe promotional actions (Widera 2019). Therefore, it is not possible based on secondary sources to describe the relationship between the political strategies of the regions and their marketing strategies. In-depth research in that area is needed. A 


\section{Denisa Jánošová, Tomasz Jobczyk}

juxtaposition of the scientific theoretical descriptions and real activities of the political authorities of the regions will enable a definition of the scientific gap and deficiencies in the practice of managing regional governments. Working out a model of using marketing activities in creating political actions may result in improving the effectiveness of the region activities towards the region development. A synergy of the indicated areas may contribute to a growing interest in a region, building an offer directed to the selected market segments, and in effect different from the competitors.

\section{Cohesion of political activities and marketing management in a region}

'Holding political power in a region is directly related to the idea of managing a local government, which is related to marketing management, and that is further directly related to the idea of public management. Public management as a sub-discipline of management, located at the meeting point of two scientific disciplines according to the view of Szumowski, is particularly affected by the lack of systematisation and non-cohesion of terms. The researchers differentiate traditional public management, which is equivalent to administration and managerial directing of public, connected with the concept of new public management' (Widera 2019). In practice each of them is subjected to the regions functioning to guidelines resulting from the creation of regional policy. In the opinion of Barbara Kożuch (2011: 17-74; Szumowski 2014: 88), public management may be defined from many perspectives. The main perspective is the identification of the management with the activities of public institution, which is further determined by the process of political elections.

Paweł Romaniuk (2010: 162) identifies management with the provision of public services, which basically leads to the common satisfaction of public needs regardless of the method of organisation of the very satisfaction. Another definition context integrates the so called normative orientation related to the traditional understanding of public administration and instrumental orientation of the general management. Particular importance is assigned to the system of values and processes leading to the efficiency of political organisations. Each of the organisations should use the available internal resources and also the surrounding resources optimally in the process of attainment of the formulated objectives. The essence of correct public management is to understand "public management as an effective operation of the whole system instead of particular organisations, whereas an important element differentiating it from other types of 
management is its simultaneous association with solving structural problems, mainly with regard to creating the public sphere structure' (Widera 2019; König 2003: 4; Kożuch 2005: 16).

In marketing management performed on the regional level the following key features may be indicated:

1. Marketing management in a region should be shaped by the awareness of the political authorities of their long and short-term objectives, and whether the objectives are cohesive with the plan for regional development, considering the development of residents as a priority.

2. Marketing management should comprise innovativeness and systematic use of the available knowledge.

3. Its implementation must be based on a professional team, open to using the experiences of other regions.

4. The essence and benefit of using marketing activities should be supported by local communities, which should be reflected in educational activities.

5. Educational actions for the residents may not be omitted in the activities of the political authorities of a region, which assign tasks to marketing services.

6. The main role in marketing management is played by the political authorities of the region. They should be the ones to delegate activities and monitor the effects.

7. Building marketing activities may take place based on internal services or be outsourced to external organisations.

8. As regards extensive marketing activities carried out by regional authorities and supporting organisations, an above-standard model of actions is needed compared to the currently applied methods of coordination.

9. Marketing management of a region, cohesive with political actions, should be determined by strategic objectives. Strategic planning may not be a one-off activity. It must be continuous and based on setting out the particular stages. A strategic plan is a fundamental tool in marketing management of a region (Florek 2007; Jędrzejewski 2018: 83-95).

The development of regions in Poland may not be solved solely by mobilisation of local resources. Regional policy must be cohesive with politics. Not all regions may develop, as their resources differ. Territorial marketing based on the implementation of the marketing concept 


\section{Denisa Jánošová, Tomasz Jobczyk}

focuses on the creation of regional and local products. It is particularly directed to foreign investors. It may be said that economic globalisation resulted in the setting up of a global market of foreign investments. Therefore, activities on regional and consequently on local level are essential. They significantly affect the maintenance of regions which are directed towards attracting investments. Building local development based on foreign projects is extremely important. A significant requirement while considering regional policies is to take into account the trend that in developed market economy countries foreign investments are more difficult to enforce. It is because the target country usually imposes harder investment conditions. It is also important to consider that with regard to large investment projects the political role of national authorities is as important as the willingness of the regional authorities. In that case the political dependence may be seen. The role of regional and local marketing is the performance of a continuous process of preparing the region as a product offered to investors. In such formulated strategy extremely important are the local marketing services within the resources of local authorities who cooperate with the marketing services of the region on a regular basis. Nevertheless, despite the obvious need for the existence of such system , this usually boils down to promotional and public relations activities. PR and promotional programmes do not concentrate, however, on the very regional and local product. And the latter is usually a highly imperfect one. The marketing formulation of regional and local products should take into account many factors which contribute to the attractiveness of a product.

\section{Marketing information system in the resources of local political authorities}

A proper tool for cohesive political activities and the supporting marketing activities in a region is a marketing information system. The role of the system is to systematically estimate the needs related to information, processing of the essential data and provision of the data at the proper time to the staff creating political processes in the region with the use of subordinated organisational structures. A marketing information system is a domain where people and procedures interact. The system uses tools selected adequately to the current needs. It adapts solutions which best facilitate its operation. It is an ordered collection of information, operating in accordance to the purposefully applied programmes, which exports adequate information to the inside and outside of the organisation. The information is a supporting tool in taking decisions by the political authorities. 
There is no universal, model system of marketing information. Each organisation should independently shape the system by analysing their needs and solutions already applied. The system organised for the regional authorities should comprise functionalities for the subordinate institutions. The system is an extensive collection updated on a current basis, which should extend its resources as well as the tools it is using. The components of the system include: for example marketing survey, marketing research, or supporting of marketing decisions. An essential element is gaining information as a result of the research. Political authorities are dependent on their electors, therefore, knowledge of the voters' views should determine decision making. One of the reasons for carrying out marketing research is striving for the reduction of risk of making faulty decisions. The research may support regional authorities in launching and developing a project or long-term activities. A marketing information system uses statistical methods, data collections, models and techniques. It is important for the system that adequate tools are available to enable collection and interpretation of the extending sets of information, for the purpose of their transformation into a base for marketing activities. Decision-making models and statistical methods are tools which transform all of the collected data in the researched area into information of real value for the marketing services supporting the regional political authorities and mangers. Models enable the understanding of marketing problems, foreseeing market events and determining the possible consequences of marketing activities (Klisiński \& Widera 2006; Kotler 1994: 117-134).

\section{Importance of quality in regional political actions models based on the practical application of marketing}

The achievements of applied marketing on the economic market resulted in the rephrasing of the term of quality from internal into an external one. It is now identified with the quality for the consumer. Quality, perceived from the marketing point of view, is a collection of features and characteristics of the service provided, which affect the capability of satisfying the research-determined or presumed needs of a customer. The quality of services directly affects the fulfilment of customers' expectations and their satisfaction from the transaction. If the quality perceived by the person acquiring a service does not coincide with the person's expectations, it may mean that the person will not acquire the service in the future or will turn to a competitive offer. As opposed to technical quality referring to the material importance of service, which may 
be assessed and controlled more easily, image is a phenomenon much more difficult to assess. On the political market, the image of a politician and their party is one of the key determinants whether they receive a mandate to rule as a result of democratic elections. In the eyes of electors, the image is related to the quality of tasks performed within the occupied position. A regional politician is responsible for the quality of the services of the organisation they manage. As regards a region - this refers to regional government. Identification of faults in the quality of the services provided is one of the key elements creating the risk of losing the authority exercised. When referring to the experience of marketing, basic determinants which contribute to bad quality services may be listed. They include:

1. Discrepancy between the assessment by the political authorities of the regional development strategy implemented and the development contributing value.

2. Discrepancy between the expectations of the regional government stakeholders and the assessment of the expectations.

3. Discrepancy between the assessment by the regional government managers of the quality of the services provided and the actual quality thereof.

4. Discrepancy between the assessment by the regional managers of the effectiveness of communication with the stakeholders and assessment of the communication quality made by the stakeholders themselves.

5. Discrepancy in the assessment of the quality of the subordinated services.

6. Discrepancy in the assessment of the problems solved.

7. Discrepancy in the assessment of the extend and the usefulness of availing of knowledge and innovation, which should contribute to the improvement of the quality of the services provided.

8. Discrepancy between the assessment of the usefulness of the applied tools and their actual usefulness.

9. Discrepancy between the quality of the regional product prepared and its actual buying power.

The generally understood quality of the regional political authorities and the subordinated services should be assessed. The principle is only partially followed and refers mainly to employee assessment. 
It is not applied towards the ruling politicians. In practice, the quality of their activities is verified in a democratic election. The election is in fact a key element in ruling, however, in that regard regional management seems to be insufficient. Creation of the mechanisms of periodical assessment with the use of scientific methods, for example, will not only contribute to a higher probability of repeating an electoral success but, which is more important, may be a factor leading to the improvement of the quality of political authority regardless of the interrelation of its assessment and the elections.

Diagnosing discrepancies in the assessment of quality may be carried out by way of comparison. The quality of regional development may also be tested with the use of benchmarking. The principle is to compare the region's development level to the development of other regions in the country. The actions are combined, for example, by an assessment of the quality of life for the residents, the value of investments, economic potential, number of higher education facilities, their rankings, or the number and quality of organisations providing public services. In a more advanced assessment, engagement of citizens in social life may be compared, e.g. by way of analysing the number of NGOs. An assessment in reference to a country only may not be sufficient, as the EU's binding principles, including the freedom of movement and residence, may cause that low quality of a region, and especially of it'se labour market, will contribute to emigration. Subsequently, the latter will lower the professional and intellectual potential of the region. The necessity of making comparisons to the other European regions is, therefore, highly justified. Even more so, because the concept of the development of the European Union has been perceived through regional development.

\section{Conclusion}

By presenting the selected interrelations between regional policy and regional marketing, the intent of the authors of this article was to emphasise that regional policy should incorporate marketing methods, techniques and tools. This refers particularly to territorial marketing, which is mostly understood as regional marketing. In the practice of managing a region and local areas, marketing is used to a lesser extend and is usually associated with promotional actions, which does not mean that such understanding of it is correct. Political actions in the term of ruling, and particularly during election campaigns, are based on political marketing. It is, therefore, hardly understandable that the awareness of the people managing the region and ruling as result of a 
democratic decision of voters is so low when compared to the advantages brought about by supporting development actions based on marketing. It is hard to imagine a market success in the economic sphere without including marketing management in the management of a company. How, therefore, are regions and local areas to achieve success without being supported with marketing when they are subject to competitiveness processes? Perhaps the reason for a failure to understand that correlation is insufficient knowledge among the political creators with regard to transferring economic mechanisms to the social sphere together with the positive effects brought about by that phenomenon. Perhaps the regional services which participate in managing a region do not sufficiently avail of scientific resources. Obviously the reasons for such situations are multiple but when referred to the operating practices of fast developing regions, and at the same time to the scientific output, it is hard to contradict a thesis that in contemporary times there is no organisation on the market which may continue without marketing.

\section{References:}

DeVito, J, A.(2001). Basics of interpersonal communication. Prague: Grada Publishing.

Florek, M. (2007). Promocja w marketingu terytorialnym, Podstawy marketingu terytorialnego. Poznań: Wydawnictwo Akademii Ekonomicznej w Poznaniu.

Jędrzejewski, K. (2018). Zarządzanie marketingowe jako czynnik rozwoju gminy. Kwartalnik Nauk o Przedsiębiorstwie, 48 (3), 83-95.

Kita, J. et al. (2000). Marketing. Bratislava: Iura Edition.

Klisiński, J., Widera, Z. (2006). Marketing terytorialny aspekty lokalne. Katowice: Unikat2.

Kotler, F. (1994). Marketing, analiza, planowanie, wdrażanie i kontrola. Warszawa: Geberthner i Ska.

Kożuch, B. (2011). Skuteczne współdziałanie organizacji publicznych i pozarządowych. Kraków: Instytut Spraw Publicznych, Uniwersytet Jagielloński.

Romaniuk, P. (2010). Pojęcie zarządzania publicznego w samorządzie terytorialnym. Studia Prawnoustrojowe, 11, $161-70$.

Strussová, M. (2007). The regional dimension of the socio-spatial identity in Slovakia. In: Trends in regional and local development in Slovakia (pp. 93-114). Nitra: Institute of Ethnology SAV, European Policy Centre, Department of Ethnology and Ethnomusicology.

Szumowski, W. (2016). Zarządzanie publiczne - próba systematyzacji koncepcji. Wrocław: Wydawnictwo Uniwersytetu Ekonomicznego.

Widera, W. (2019). Marketingowa strategia pozyskiwania i integracji imigrantów na potrzeby rynku pracy w województwie ślaskim. Katowice: Uniwersytet Ekonomiczny w Katowicach, PhD thesis. 